\title{
Feminism and Islamophobia
}

\author{
By/ Abdallah Mahmoud Shafiq
}

PhD student At Helwan University 


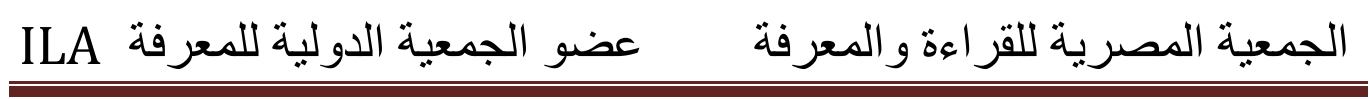




\section{Feminism and Islamophobia:}

Islamic feminism has been heatedly debated; secular feminists reject it because they argue that religions in general and Islam in particular are oppressive to women while many Muslim women reject it because they feel that 'feminism' is a secular invention imposed on them from outside, from the West. On the other hand, Islamic feminism has also been widely embraced by both activists and scholars. They regard it as a tool to counter these allegations and misconceptions. They try hard to discard these wrong attitudes by introducing new works that confront that misunderstanding. For example, Margot Badran in her article, "Islamic feminism" asks, what's in a name? What's behind a name? What is Islamic feminism? She writes:

I am not a Muslim, but I find myself fascinated and genuinely interested in the question of women and Islam. I do not under any circumstances start my engagement with the topic from a position which neither reduces Islam to be monolithic and antiwomen nor a position which states that secularism is the only route to women's empowerment. What interests me in this topic is the dynamic nature of Islam exploring the different interpretations of the same text historically and presently and how Muslim women across the region frame their arguments within Islam in their attempt to bring about law reform. But first, we need to step back, and take a closer look at what the phenomenon of Islamic feminism might actually refer to (4).

According to Badran, the concept of Islamic feminism refers to a "feminist discourse and practice articulated within an Islamic paradigm" (4). The term "Islamic feminism" began to surface in 


\section{ILA الجمعية المصرية للقراءة والمعرفة عضو الجمعية الدولية للمعرفة}

the 1990s in various global locations. The notion of arguing for women's rights through an appeal to Islam's basic values was manifest in the calls of a number of pioneering women writers and activists in the Arab region since the end of the 19th century. A'isha Taymur(1840-1902),Malak Hifni Nasif (18861918), A'isha Abd al-Rahman (1912-1998), Hoda Sha'rawi (1879-1947), and Nazira Zayn al-Din (1908-1976) - despite their diverse contexts, social backgrounds, and nature of their activism - all expressed their demands for women's rights within the family, in education, work, and political participation within an assumed Muslim frame of reference.

It also appeared in the writings of Muslims. Iranian scholar Ziba Mir-Hosseini exposed the rise and use of the term Islamic feminism by some women, as well as men, writing in the Teheran women's journal Zanan, founded by Shahla Sherkat in 1992. Saudi scholar Mai Yamani used the term in her 1996 book Feminism and Islam. Nilüfer Göle, in The Forbidden Modern, used the term Islamic feminism to describe a new feminist paradigm emerging in Turkey (Göle 7). Also, South African activist Shamima Sheikh frequently employed the term Islamic feminism in her speeches and articles.

By the mid-1990s, there was growing evidence of Islamic feminism as a term created and circulated by Muslims in far flung corners of the world. The term (Islamic feminism) is now being produced at diverse sites around the world by women inside Muslim countries like Omaima Abu Bakr in Egypt. But Islamic feminism is also growing in Muslim Diaspora with scholars such as the Pakistani-American Asma Barlas and, in convert communities in the 
West, with activists/writers such as the African-American Amina Wadud. According to Margot Badran, Islamic feminism emerged out of a critique of both patriarchal Islam(ism) and of secular feminism (Badran 11).

Omaima Abou-Bakr, a professor at Cairo university and a founding member of the Women and Memory Forum, writes that the Islamic feminist project is a "continuous attempt to un-interpret past gender biased readings done by male jurists and to offer alternative new perspectives toward justice and equality within Islam itself" (12). In her analysis of the achievements of Islamic feminism thus far, she says that "it has proven the possibility of undoing the doings of patriarchy" (15). Islamic feminists argue that although the term or the concept itself originated in the West, the ideas behind it are not inventions of the West. A similar case can be found in the term and concept of democracy. It is also a term that originated in the West, but the ideas behind it are present in Islam through the concept of Shura (consultation) (Tønnessen 49).

In an interview, Omaima Abu Bakr assesses the validity of using the term "Islamic Feminism":

It is true I did not reject it because it depends on what you put under the name, how you define and qualify it, and what are the ideas and notions you subscribe to under that name. It is true that the terms "feminism" and "gender" themselves are English and Western, but the ideas of egalitarianism, justice, equal rights, compassion, resistance to tyranny, activism...etc. are not a Western invention or a monopoly by the West. Especially the history of women in the Arab world in the 19th and 20th 


\section{ILA الجمعية المصرية للقراءة والمعرفة عضو الجمعية الدولية للمعرفة}

century shows their "feminist activism" and discussion of "gender" long before these terms came to the surface (Abu Bakr13).

By insisting on using the term "Islamic feminism" the Muslim writers are trying to show that the West does not have the monopoly of defining "feminism." Omaima Abu Bakr argues that "Islamic Feminism" allows me to qualify my own indigenous brand of feminism and work out a feminist discourse stemming from within the culture and religion. There is an Islamic ethics of feminism" (Abu Bakr14). As Margot Badran has argued, Islamic feminism has emerged out of a critique of both patriarchal interpretations of Islam and secular feminism. In the West, the dominant strand of feminism has been secular. Although there are examples of Christian theologians using the bible to argue for women's rights (Allyson Jule and Bettina Tate Pedersen 44), the dominant views among Western feminists have been that religion is oppressive to women. However, it should be noted that the history of Western secular feminism is diverse, ranging from Marxist feminism to liberal and radical feminism. There are also models which do not advocate gender equality. For example, the first wave of feminist activism was preoccupied with women's entry into the labor force and also with women's political rights.

Moreover, Islamic feminists are critical towards the historical stereotypes which link the oppression of women among Muslims to Islam, and which define Muslim women as the other of 'Western' secular feminists: 
The anchoring of the struggle for women's rights in a religious orientation to the world (as undertaken by Islamic feminists) also challenges the tendency towards monopolizing the struggle for women's rights (by Western feminists), and towards universalizing secular models of thought which have characterized 'Western' feminism. So, although Islamic feminists accept principles of gender equality as stipulated in the universal human rights, they reject the idea of feminism based on secularism. As such, they are demanding their rightful place in the history of feminism (Abu Bakr 22).

The representation of Muslim women and the debate of women's rights in Islam have always been at the forefront of a cultural battle between the West and the Muslim world, as these two territorial, religious and civilizational blocks share a long history of hostility in the forms of crusades (militarily), colonial/neo-colonial interventions (politically) and persistent denigration (ideologically). In the current academic debate on the prejudicial attitude and misrepresentation of Islam and Muslims, the term Islamophobia is used extensively to capture a wide range of negative sentiments against and misconceptions about the religion and its adherents. The word "Islamophobia" appeared first in an essay written by Orientalist Étienne Dinet in 1922 (Cesari, 2011, p. 11). Edward Said may have been the first to utilize it in English in a 1985 article entitled "Orientalism reconsidered" (Moten, 2012, p. 4). It is now "a useful shorthand way of referring to the dread or hatred of Islam and, therefore, to the fear or dislike of all or most Muslims. Such 
dread and dislike have existed in Western countries and cultures for several centuries" (Runnymede Trust, 1997, p. 1).

Since the Runnymede Trust in Britain published Islamophobia: A Challenge for Us All (1997), the issue has received renewed attention politically, intellectually, religiously and culturally. The word seems to have emerged in the late 1980s and early 1990s. But the phenomenon dates back centuries." Abbas (2004, p. 28) concurs with this and argues:

Although the term is of relatively recent coinage, the idea is a well-established tradition in history. Since the genesis of Islam in 622, Europe's awareness of Muslims has been overwhelmingly negative. During this long contact, the established European powers have found it convenient to portray Islam and Muslims in the worst possible light, so as to prevent conversion and to encourage European resistance to Muslim forces on the borders.

This article wants to assert and focus on one specific aspect of Islamophobia - gendered Islamophobia - and argues that it is widespread in the writings of a section of feminist scholars. Many in the West denigrate and stereotype Islamic teachings and brand them as oppressive to women in order to establish "an essentialist bifurcation of 'egalitarian West' versus 'oppressive Islam'" (Ho, 2007, p. 290). It contests such misconceptions which are results of ignorance, prejudice and the overbearing effects of colonial adventures. Many feminist scholars of Muslim societies follow the colonial discourse of feminism, characterizing Islam as misogynistic and gender oppressive. They tend to replicate Western feminist 
universalism to ameliorate women's condition there. It concludes this discussion by proposing that deprecating Islamic teachings for the service of feminism and imitating Western feminist movements may not be the correct approach to address gender oppression in Muslim societies. Both feminist and Islamically-inclined scholars should engage in dialogues to understand one another and emphasize the primordial Islamic principle of justice, in general and gender egalitarian aspects of Islam, in particular, to establish women's rights.

In the same track, the cover page of Peter Gottschalk and Gabriel Greenberg's Islamophobia: Making Muslims the Enemy (2008) carries a cartoon image of a veiled Muslim woman. This, perhaps, suggests a link between Islamophobia and the woman's position in Islam. A key element of the broader notion of Islamophobia is "Islam's alleged oppression of women", which is based on "a discourse of protecting women's rights" which enables "Islam to be portrayed as inherently misogynistic" (Ho, 2007, pp. 296-290). Zine (2004, p. 117) uses the term "gendered Islamophobia" to describe the discourse of representing Islam as inherently gender oppressive, and Muslim women as miserably oppressed by the religion. Ho (2007, p. 290) argues that such a discursive act of negatively representing Islam is "part of a broader history of colonial feminism that legitimated Western supremacy through arguing that colonial societies oppressed 'their women' and were thus unfit for self-governance."

Thus, the usual (and often absolute) embodiment of Muslim culture and stereotypes are this: Muslim men are polygamous and abusive, and Muslim women are "veiled, shackled, and secluded" 
Thus, the usual (and often absolute) embodiment of Muslim culture and stereotypes are this: Muslim men are polygamous and abusive, and Muslim women are "veiled, shackled, and secluded" (Hasan, 2005 , p. 27) and forced into marriage and caged in the hijāb; after all, Muslim women are positively represented as perhaps the most pitiable people on earth and as victims of a patriarchal and oppressive religion: Islam.

This obsession with the Muslim women's plight to assert the supposed moral ascendancy of the West and to create an artificial urgency to save brown women from brown men is generally associated with "colonial feminism" (Ahmed, 1992, p. 163). It maintains a "clandestine project of globalizing the West's hegemonic culture and provincializing eastern-Islamic cultural practices," which in turn "artificially creates a desire among" a section of Muslim society "to emulate the dominant Western culture, deemed to be true for all" (Hassan, 2005, p. 50). Such feminist Universalist assumptions homogenize Muslim women and Islamic traditions and tend to establish Western cultural hegemony.

The tendency to see Muslim cultures as monolithic is the foremost feature of Islamophobia (Abbas, 2004, p. 29). As Allen (2001, p. 3) states, "The most dangerous aspect of Islamophobia" is to caricature Islam as "entirely uni-dimensional and monolithic without any internal differentiation or opinion." Scholars from both the East and West now widely acknowledge that a complicity between a section of Western feminism and the colonizers/neocolonizers, who steal "feminist rhetoric" (Viner, 2002) to advance colonial interests and to support imperialist wars of occupation, has played a role in buttressing these cultural assumptions. The negative 
representation of the "Islamic East" portrays Muslim women as in need of help from the "civilized" West for emancipation from patriarchy. And this, in turn, facilitates the introduction of Western feminist models and concepts of women's rights in Muslim societies. The demonization of Islam and the construction of Muslim men as religiously and culturally misogynists and Muslim women as passive, powerless and quintessential victims of "Islamic patriarchy" arise from prejudice because Islam is generally singled out to be associated with women's inferior position and oppression.

It is obvious that women do not fare very well in the doctrinal teachings of other world religions such as Hinduism, Judaism and Christianity. However, these religious traditions are not at the forefront of media hype or academic debate when women's inferiorized status in religion is discussed. Conversely, in academia and mass media, Islam is routinely regarded as the deviant "Other" and essentialised in a quintessentially Orientalist manner. Incidents of gender violence in Muslim societies are broadcasted and "[s]weeping generalizations are then made about all Muslims, in ways which would not happen in the case of, for example, all Roman Catholics, or all Germans, or all Londoners" (Runnymede Trust, 1997, p. 5).

Interestingly, the Islamic position of women may corroborate many rights such as, the rights to education, employment, property, equal payment, independent personhood, political representation and the initiation and dissolving of marriage, among others, which women enjoy in today's West. However, that likeness does not seem to ensure any check on the rise of gendered Islamophobia in the West, especially in the post 9/11 era. This confirms Werbner's 
(2005, p. 8) argument that, "like other phobias and racisms," Islamophobia is "an incapacity to cope not only with difference but with resemblance." If charges of misogyny against Islam are true, the religion resembles medieval Europe; and if the charges are unfounded and based on misapprehension of the religion, and if Islam is proved to be gender egalitarian, then to a great extent there exist commonalities between its treatment of women and women's independence in today's West. Despite these supposed resemblances, Islamophobia in the West has continued unabated. Perhaps, these supposed resemblances engender a civilizational rivalry and provoke the West to dread and caricature Islam, which is now known as Islamophobia. Ignorance about women's actual status in Islam is quite widespread. As Ahmed (1982, p. 522) states:

Just as Americans 'know,' that Arabs are backward, they know also with the same flawless certainty that Muslim women are terribly oppressed and degraded. And they know this not because they know that women everywhere in the world are oppressed, but because they believe that, specifically, Islam monstrously oppresses women.

In the same way, Bullock (2002, pp. xv-xvi) argues that many "sophisticated" feminist scholars - Muslims and non-Muslims alike - believe that "Islam, like any patriarchal religion, subordinates women." Such negative portrayals of Islam underpin Islamophobic clichés and are predicated upon a common notion that "human rights can exist only within a secular context and not within the framework of religion" (Hassan, 1996, p. 363). This doctrine of antithesis of Islam and women's rights is a result of inadequate knowledge about Islam. Mistaken notions of Islam inevitably lead a section of 
Western feminist scholars to caricature Muslim society. While spreading misconceptions about women's status in Islam, they try to project "the secular, Western path" (Bullock, 2004) as the only way to liberate women. Needless to say, many secular feminist intellectuals in Muslim countries uncritically subscribe to such views. Because of the proliferation of Western feminist ideas, many in the Muslim world believe that emulating the West uncritically and discarding Islamic practices is the only way to emancipate women. Ahmed (1992, p. 54) interprets Cromer's paradox of "supporting" women's causes in Egypt thus: "Whether in the hands of patriarchal men or feminists, the ideas of Western feminism essentially functioned to morally justify the attack on native societies and to support the notion of the comprehensive superiority of Europe." Although Cromer was opposed to the idea of women's empowerment in Britain, his supposed concerns for women's rights in Egypt had a different dimension and a corresponding driveshaft a $\mathrm{n} \mathrm{d} \mathrm{w} \mathrm{e} \mathrm{r}$ e interwoven with his colonial assignment in the country. So, as Bullock (2002, p. 21) argues, Amin and Cromer's "concern for the status of women was hardly a concern for women." Hassan (1996, p. 368) comments on this artificial love of the West for Muslim women thus:

In the midst of so much hatred and aversion toward Islam and Muslims in general, the out-pouring of so much sympathy, in and by the West, toward Muslim women appears, at a surface level, to be an amazing contradiction. For are Muslim women also not adherents of Islam? And are Muslim women also not victims of 'Muslim-bashing'? Few Muslims can forget the brutal burning of Turkish Muslim girls by German gangsters or 


\section{الجمعية المصرية للقراءة والمعرفة عضو الجمعية الدولية للمعرفة ILA}

the ruthless rape of Bosnian Muslim women by Serbian soldiers.

During the colonial period, and even more so in postcolonial times, the West has largely been hostile to Islam and to its adherents. In the post $9 / 11$ era that has witnessed an extraordinary, dramatic backlash against Muslims around the globe, such Islamophobic tendencies are a common feature of most Western media and governments. However, despite this palpable antagonism against Muslims, there seems to have been a perennial "feminist" concern for Muslim women, which may not be for their emancipation from patriarchy or from a supposedly repressive religion. It is rather a project of Westernizing Muslim cultures and of distancing Muslims from Islam, which eventually facilitates imperial intervention and domination. In the long run, such ideas only create confusion and division in Muslim society, while the underprivileged and subjugated women continue to be a pawn in this cultural battle fought in their names. Needless to say, in such colonial feminist propaganda, Islamic practices are always painted most negatively (Bullock, 2002, p. xxx).

Worth saying that, the pro and the anti Islamic feminism should search for a meeting point in order to push women's rights forward. Going against Islam or blaming culture for women's oppression and then seeking solutions in a secular, foreign ideology takes Muslim societies nowhere. It would be far better received and more effective if Muslim men were reminded of the teachings of Islam that obligate them to be just and compassionate to women. As such, feminist scholars in Muslim societies should insist on "a feminism that is indigenous" (Bullock, 2002, p. xxii) 
Secular feminists and Islamic feminists in Muslim societies may disagree on certain issues. However, if they can agree on promoting "justice" and preventing an "oppressive attitude" in the broader sense, then, the gates are opened to a wide range of areas where they may cooperate and work together including but not limited to "education, spousal abuse, humane treatment for women and so on" (Bullock, 2002, p. xxviii). They may also unite against the capitalist maneuvering of the female body, as a shared campaign to stop "the use of women's bodies for selling commodities, the competition amongst women to be beautiful to attract men's attention" which would appeal "to secular leftists, feminists, and religious scholars alike" (Bullock, 2002, p. 90). As a woman in Turkey declared to Fernea (1998, p. 217): "What secular and religious women need to do is stand together. We'll all be stronger for learning about each other. But cutting each other down weakens us all."

Unfortunately, with regard to the question of women's rights, "Islamists" and secularists in Muslim societies have become so hostile to one another's views that a dialogue between them seems rather impossible. Women's rights activists of both secular and Islamic orientations had a chance to discuss gender issues at the Beijing Global Women's Conference in 1995. Sadly, their sharp disagreements and debates turned their discussion groups into, to use Wadud's (2002) words, "screaming sessions." The fact of the matter, however, remains that if feminists are passionate about promoting women's rights (and not merely importing foreign ideas in the name of feminism), and if Islamists believe in the primordial, ahistorical Islamic principle of justice, then there should be innumerable avenues for both groups to work together in synergy, as mentioned 
before. Such sanity, however, seems very farfetched in most Muslim countries. The reason for this is perhaps that both Islamic and secular forces believe that Islam is essentially anti-feminist. Hence, regarding women's rights, secularists keep themselves distanced from Islam and the Muslims from feminism. A hope for reconciliation between the two camps may, nonetheless, not be logically impossible or simply wishful thinking if the two parties can communicate and understand each other. While "Islamists" need to appreciate the legitimate feminist concerns and should not dismiss feminism simply because it originates in the West, secular feminists should review some of their ideas for compatibility checks against cultural specificities and should appreciate and highlight aspects of gender egalitarianism in Islam. Rigidity in feminist work is not very helpful because feminism's "worst enemies have been those who have treated "feminism" like a new religion with dogmas that can allow for only one possible interpretation" (Marks, et al., 1990, p. 73).

To conclude, Feminism, meaning the pursuit of gender justice, is a noble movement that battles inequities and has contributed significantly to establishing the dignity and independence of women. Conversely, Islamophobia, similar to anti-Semitism or any other religious prejudices, depicts religious hatred and is a form of racism. These two ideas - feminism and Islamophobia - are sharply opposed to each other, as their ideological bases are totally different. So appropriating feminism to fuel Islamophobia is not only inappropriate, but a deep affront to all women who have been suffering from male oppression in various corners of the world and to all those people who have been battling the patriarchal social apparatus in order to remove gender injustices. This thesis has 
intended to create awareness among feminist activists and scholars so that they may play a pivotal role in resisting Islamophobic tendencies in feminist discourses. The aim of this paper is not to tarnish other religious traditions or to debase their followers. What is attempted here is to show the double standards some feminist scholars maintain while talking about women in Islam, as they seem to have singled out the religion as particularly misogynistic. While many Western scholars have begun to appreciate the emancipatory and gender egalitarian aspects of Islam, the caricaturing of religion has gone unabated and is simply overwhelming. Feminist concerns for Muslim women should equate respect to what they believe. Deprecating their religion while struggling for their rights may not bring any good for them.

While discussing Western feminism, the intention has not been to make sweeping generalizations about it, rather has been to refer to a damaging propensity among a section of feminist scholars that seek to undermine the religion of Islam. Muslims may have reservations about some elements of Western feminism, but what they must admit is that it has brought the issue of women's oppression to the forefront of everybody's mind, which has also influenced the women's rights movements in the Islamic countries. The question now before Muslims is: What framework should be followed - the Western or the Islamic? In` the same track, following the negative strategy of denigrating Islam to establish women's rights in Muslim societies has not rendered any good service to women or to feminism. 


\section{References:}

Abbas, T. (2004). After 9/11: British South Asian Muslims, Islamophobia, multiculturalism, and the state. The American Journal of Islamic Social Sciences, 21(3), 26-38.

Abu-Lughod, L. (1998). Introduction: Feminist longings and postcolonial conditions. In L. Abu-Lughod (Ed.), Remaking women: Feminism and the modernity in the Middle East (332). Princeton: Princeton UniversityPress.

AbuSulayman, A. A. (1993). The crisis of the Muslim mind.

Herndon, Virginia:International Institute of Islamic Thought.

Ahmed, L. (1982). Western ethnocentrism and perceptions of the harem.Feminist Studies, 8(3), 521-534.

Ahmed, L. (1992). Women and gender in Islam. New Haven: Yale UniversityPress.

Allegretto-Diiulio, P. (2007). Naguib Mahfouz: A Western and Estern cage of female entrapment. Carlisle: Cumbria Press. Allen, C. (2001). Islamophobia in the media since September 11th.

Paper presented at Exploring Islamophobia: Deepening our understanding of Islam and Muslims. University of Westminster, 29 September 2001.Retrieved February 15, 2012 from http://www.scribd.com/rshiaty/d/71578290Islamophobia-in-the-Media-Since-911-Christopher-All-En. Annan, K. (2004). Press release SG/SM/9637 HR/4802 PI/1627. Now York: United Nations. Retrieved February 15, 2012 from

http://www.un.org/News/Press/docs/2004/sgsm9637.doc.htm

Badran, M. (1995). Feminists, Islam, and nation: Gender and the making of modern Egypt. Princeton: Princeton University Press.

Bailey Jones, R. (2011). Postcolonial representations of women:

Critical issues for education. Dordrecht: Springer. 
Berkey, J. P. (2003). The formation of Islam: Religion and society in the Near East, 600-1800. Cambridge: Cambridge University Press.76 Intellectual Discourse, Vol 20, No 1, 2012

Bullock, K. (2002). Rethinking Muslim women and the veil:

Challenging historical \& modern stereotypes. Herndon, Virginia: International Institute of Islamic Thought.

Bullock, K. (2004). Hijab and contemporary Muslim women. The Message International, February - March.

Butler, G. C. (1960). Kings and camels: An American in Saudi Arabia. New York: Garnet. Carlton club allows women members. (2008, May 22) BBC. Retrieved July 25, 2011 from http://news.bbc.co.uk/2/hi/uk_news/politics/7414279.stm. Christian, B., duCille, A., Marcus, S., Marks, E., Miller, N. K., Schaffer, S., and Scott, J. W. (1990). Conference Call. Differences: A Journal of Feminist Cultural Studies 2(3): 52108.

Deen, H. (1999). Broken bangles. New Delhi: Penguin.

Deen, H. (2006). The crescent and the pen: The strange journey of Taslima Nasreen. Westport, CT: Praeger.

Cesari, J. (2011). Islamophobia in the West: A comparison between Europe and the United Sates. In J. L. Esposito \& I. Kalin (Eds.), Islamophobia: The challenge of pluralism in the 21st century (pp. 21-45). New York: Oxford University Press.

El Guindi, F. (2003). Veiling resistance. In R. Lewis \& S. Mills (Eds.), Feminist postcolonial theory: A reader (pp. 586-612). Edinburgh: Edinburgh University Press.

Fernea, E. W. (1998). In search of Islamic feminism: One woman's global journey. New York: Doubleday.

Fernea, E. W. (2000). The Muslim women's movement is discovering its roots in Islam, not in imitating Western feminists. Retrieved October 27, 2011 from http://www.ssc.upenn.edu/ kuhn/temp. 
Gewen, B. (2008). Muslim rebel sisters: At odds with Islam and each other.The New York Times, April 27, 2008. Retrieved February 15, 2012from

http://www.nytimes.com/2008/04/27/weekinreview/27gewen

html?pagewanted=all.

Gottschalk, P. \& G. Greenberg. (2008). Islamophobia: Making Muslims the enemy. Plymouth: Rowman \& Littlefield.

Grimes, W. (2007). No rest for a feminist fighting radical Islam. The New York Times, February 14, 2007. Retrieved February 15, 2012 from

http://www.nytimes.com/2007/02/14/books/14grim.html?pag ewant

Hasan, M. M. (2005). The Orientalization of gender. The American Journal of Islamic Social Sciences, 22(4), 26-56.FEMINISM AS ISLAMOPHOBIA/MD. MAHMUDUL HASAN 77

Hasan, M. M. (2010). Free speech, ban and "fatwa": A study of the Taslima Nasrin affair. Journal of Postcolonial Writing, 46(5), 540-552.

Hashmi, T. I. (2000). Women and Islam in Bangladesh: Beyond subjection and tyranny. London: Macmillan.

Hassan, R. (1996). Rights of women within Islamic communities. In J. Witte \& J. D. van der Vyver (Eds.), Religious human rights in global perspective (361-386). The Hague: Martinus Nijhoff.

Hassan, R. (2007). Religion, ethics and violence: Developing a new Muslim discourse. In B. K. Goldewijk (Ed.), Religion, international relations and development cooperation (161186). Wageningen: Wageningen Academic Publishers.

Hirsi Ali, A. (2006). The caged virgin: An emancipation proclamation for women and Islam. New York: Free Press.

Ho, C. (2007). Muslim women's new defenders: Women's rights, nationalism and Islamophobia in contemporary Australia. Women's Studies International Forum, 30, 290-298. 
Retrieved February 15, 2012 from

http://uts.academia.edu/ChristinaHo/Papers/971244/Muslim_ womens_new_defenders_Womens_rights_nationalism_and_I slamophobia_in_contemporary_Australia.

Khaleeli, H. (2010). Nawal El Saadawi: Egypt's radical feminist.

The Guardian,Thursday 15 April 2010. Retrieved August 7, 2011 from http://www.

guardian.co.uk/lifeandstyle/2010/apr/15/nawal-el-saadawiegyptianfeminist.

Lewis, R. \& S. Mills. (2003). Introduction. In L. Reina \& S. Mills (Eds.), Feminist postcolonial theory: A reader (1-24).

Edinburgh: Edinburgh University Press.

Moten, A. R. (2011). Modernity, tradition and modernity in tradition in Muslim societies. Intellectual Discourse, 19(1), 1-13.

Moten, A. R. (2012). Understanding and ameliorating Islamophobia. Cultura:International Journal of Philosophy of Culture and Axiology, 9(1): 63-71.MPs in Catholic Malta pass historic law on divorce. (2011, July 25) BBC.Retrieved July 25, 2011 from http://www.bbc.co.uk/news/worldeurope-14285882.

Nasrin, T. (2003). Ka. Dhaka: Chardik.

Qutb, M. (1993). Islam the misunderstood religion. Lahore: Islamic Publications.

Rahman, M. (2008). Qur'an O Hadith-er Aloke Nari (Women in the light of Qur'an and hadith). Dhaka: Islamic Foundation.

Rawi, M. (2004, February 12). Rule of the rapists. The Guardian. Retrieved February 15, 2012 from

http://www.guardian.co.uk/world/2004/feb/12/afghanistan.ge nder.

Runnymede Trust. (1997). Islamophobia: A challenge for us all. Retrieved February 15, 2012 from http://www.runnymedetrust.org/ publications/17/32.html.

Saadawi, N. (1980). The hidden face of Eve: Women in the Arab world. London: Zed Books, 1980. 
Seneviratne, T. \& J. Currie (2001). Religion and feminism: A consideration of cultural constraints on Sri Lankan women. In D. M. Juschka (Ed.), Feminism in the study of religion: A reader (198-220). London and New York: Continuum. Viner, K. (2002, September 21). Feminism as imperialism. The Guardian. Retrieved February 15, 2012 from http://www.guardian.co.uk/world/2002/sep/21/gender.usa?IN $\mathrm{TCMP}=\mathrm{SRCH}$.

Wadud, A. (2002, May 1). A'ishah's legacy. New Internationalist Magazine, issue 345. Retrieved February 15, 2012 February 15, 2012 from http://www.newint.org/issue345/legacy.htm. Weeramantry, C. G. (1997). Justice without frontiers: Furthering human rights, vol. 1. London: Kluwer Law International. Werbner, P. (2005). Islamophobia: Incitement to religious hatredlegislating for a new fear? Anthropology Today, 21(1), 2005, 5-9.

Zine, J. (2004). Anti-Islamophobia education as transformative pedagogy: Reflections from the educational front lines. The American Journal of Islamic Social Sciences, 21(3), 110-119. 